Cornell Law Library

Scholarship@Cornell Law: A Digital Repository

Cornell Law Faculty Publications

Faculty Scholarship

$1-1-2011$

\title{
Convergences and Divergences in International Legal Norms on Migrant Labor
}

Chantal Thomas

Cornell Law School, chantal-thomas@lawschool.cornell.edu

Follow this and additional works at: http://scholarship.law.cornell.edu/facpub

Part of the Human Rights Law Commons, Immigration Law Commons, International Law Commons, and the Labor and Employment Law Commons

\section{Recommended Citation}

Thomas, Chantal, "Convergences and Divergences in International Legal Norms on Migrant Labor" (2011). Cornell Law Faculty Publications. Paper 588.

http://scholarship.law.cornell.edu/facpub/588

This Article is brought to you for free and open access by the Faculty Scholarship at Scholarship@Cornell Law: A Digital Repository. It has been accepted for inclusion in Cornell Law Faculty Publications by an authorized administrator of Scholarship@Cornell Law: A Digital Repository. For more information, please contact jmp8@cornell.edu. 


\title{
CONVERGENCES AND DIVERGENCES IN INTERNATIONAL LEGAL NORMS ON MIGRANT LABOR
}

\author{
Chantal Thomas $\dagger$
}

\section{INTRODUCTION: IMPLICATIONS OF PLURAL LEGALITIES}

Multiple international legal regimes ${ }^{1}$-in human rights law, refugee law, labor law, trade law and criminal law-address, to some degree, the rights and privileges that should be accorded to aliens working within the territories of states parties. Even within these particular subject areas, let alone between them, however, "little has been done" in the way of synthesis. $^{2}$

This "substance without architecture" in international migration law may result in part from institutional costs of harmonization, the obstacles of path-dependency, or the simple lack of political will. In addition, there may be valid reasons for the lack of a coherent regime, if the "sites and topics of

$\dagger$ Professor of Law, Cornell Law School. Thanks to all those who participated in the workshop in which the original basis for this paper was presented, "Human Rights: Global Legal Pluralism Revisited," Thursday, July 26, 2007, Law and Society Annual Meeting, Berlin. Thanks also to the invaluable comments and support of the members of the Labor Law and Development Research Network and especially to Adelle Blackett.

1. Sally Merry has defined legal pluralism as a "a situation in which two or more legal systems coexist in the same social field." Sally Engle Merry, Legal Pluralism, 22 L. \& Soc'Y REV. 869, 870 (1988). This essay considers the "plural legalities" at the international level, understood as the product of multiple overlapping treaties, each of which is actually or potentially (depending on ratification status) formally binding on the state. As such, the focus of this essay departs from that of other treatments of legal pluralism which look to the interplay between binding state law and competing nonbinding norms from, for example, codes of corporate conduct or other corporate practices that may constitute "labor law without the state," Harry W. Arthurs, Labour Law Without the State, 46 U. TORONTO L.J. 1(1996). For an example of such analysis, see Adelle Blackett, Global Governance, Legal Pluralism \& the Decentered State: A Labor Law Critique of Codes of Corporate Conduct, 8 IND. J. GLOBAL LEGAL STUD. 401 (2001). For a discussion of legal pluralism as a framework for the analysis of international law, see, e.g., William Burke-White, International Legal Pluralism, 25 MiCH. J. INT'L L. 963 (2003); Paul Schiff Berman, Global Legal Pluralism, 80 So. CAL. L. REV. 1155 (2007).

2. See David Weissbrodt, The Human Rights of Non-Citizens 36 (2008) (discussing international human rights law); see also RAINER BAUBÖCK, MIGRATION AND CITIZENSHIP: LEGAL STATUS, RIGHTS AND POLITICAL PARTICIPATION 37 (2006) ("Assessing how international human rights norms shape domestic immigrant policies. . . is more difficult and has been a relatively neglected area of research").

3. T. Alexander Aleinikoff, International Legal Norms on Migration: Substance Without Architecture, in INTERnational Migration LaW: DeVeloping PaRAdigms and Challenges 467 (Ryszard Cholewinski, Richard Perruchoud \& Euan MacDonald eds., 2007). 
governance [are] simply too diffuse to permit" one. ${ }^{4}$ However, the vulnerable social position of migrant workers also raises the danger that their interests are most likely to fall through the cracks of such a patchworked legal order.

Comprehending the effects of multiple legal regimes arising at domestic, regional, and international levels is of course a difficult business, and the challenge of doing so reacts differently with different jurisprudential sensibilities: whereas some see the gradual accretion of global constitutionalism ${ }^{5}$ or at least a welcome form of regulatory competition, ${ }^{6}$ others warn of the destructive effects of fragmentation. ${ }^{7}$

Mindful of such debates, this essay investigates the international regulatory terrain affecting migration. In seeking to contribute to that effort, this essay takes up some of the underlying preoccupations of legal pluralism, which help to shed light on some of the larger questions at stake beyond the particulars. There are, to begin with, the doctrinal questions related to positive law. Central to the doctrinal analysis is the question of whether, or more precisely, where, rules from multiple regimes converge or diverge. ${ }^{8}$ While some excellent scholarship has surveyed international

4. Id. at 479 .

5. The vision of international constitutionalism arising out of the gradual accretion of norms and institutions on the basis of cumulative political deliberation emerges from JÜRGEN HABERMAS, BETWEEN FACTS AND NORMS (1990). For a discussion of Habermasian constitutionalism, see Thomas Giegerich, The Is and the Ought of International Constitutionalism: How Far Have We Come on Habermas 's Road to a "Well-Considered Constitutionalization of International Law"?, 10 GERMAN L.J. 31 (2009). For other discussions of European constitutionalism, see ALEC STONE SWEET, THE JUDICIAL CONSTRUCTION OF EUROPE (2004); JOSEPH H.H.WEILER, THE CONSTITUTION OF EUROPE: "DO THE NEW Clothes HAVE AN EMPEROR” AND OTHER ESSAYS ON EUROPEAN INTEGRATION (1999). For the constitutionalist line within international economic law, see ERNST-ULRICH PETERSMANN, CONSTITUTIONAL FUNCTIONS AND CONSTITUTIONAL PROBLEMS OF INTERNATIONAL ECONOMIC LAW (1991); for a discussion of the literature, see Jeffrey L. Dunoff, Why Constitutionalism Now? Text, Context and the Historical Contingency of Ideas, 1 J. INT'L L. \& INT'L REL. 191, 192 (2005).

6. Joel P. Trachtman, Regulatory Competition and Regulatory Jurisdiction, 3 J. INT'L ECON. L. 331 (2000).

7. For an indication of the debate, see INT'L LAW COMM'N, UNITED NATIONS, FRAGMENTATION OF INTERNATIONAL LAW: DIFFICULTIES ARISING FROM THE DIVERSIFICATION AND EXPANSION OF INTERNATIONAL LAW 12 (2006) (UN Doc. A/CN.4/L.682, 13 Apr. 2006), available at http://untreaty.un.org/ilc/documentation/english/a_cn4_1682.pdf ("Some commentators have been highly critical of what they have seen as the erosion of general international law, emergence of conflicting jurisprudence, forum-shopping and loss of legal security. Others have seen here a predominantly technical problem that has emerged naturally with the increase of international legal activity and may be controlled by the use of technical streamlining and coordination."). Andreas Fischer-Lescano \& Gunther Teubner, Regime-Collisions: The Vain Search for Legal Unity in the Fragmentation of Global Law, 25 MiCH. J. INT'L L. 999, 1004 (2004); Martti Koskenniemi \& Päivi Leino, Fragmentation of International Law: Postmodern Anxieties?, 15 LEIDEN J. INT'L L. 553 (2002).

8. The work in a related field, citizenship, has made more progress in achieving comprehensive analysis of convergence and divergence in law and policy. For a general discussion of research on citizenship law and policy and the question of convergence, see MIGRATION AND CITIZENSHIP: LEGAL STATUS, RightS AND POlitiCAl PARTICIPATION 44 (Rainer Baubcöck ed., 2006). For examples of a framework informed by pluralism, see CITIZENSHIP TODAY: GLOBAL PERSPECTIVE AND PRACTICE (T. Alexander Aleinikoff \& Douglas Klusmeyer eds., 2001). 
migration law, ${ }^{9}$ few treatments have attempted to sharpen the analysis through inquiry into convergence and divergence around specific norms and principles. Section I of this essay seeks to chart out an initial such analysis, conducting a concise comparison of particular rules affecting migrant workers from different realms of international law. Section I concludes with both a graphic representation of doctrinal convergences and divergences, and a further discussion the doctrinal relationships among treaties as elucidated through consideration of hypothetical legal disputes. ${ }^{10}$

The article considers the convergence/divergence question not only on the level of positive law and doctrine but also at the level of normative analysis. Attention to laws as norms gives proper place to the axiom recognized across numerous domains-from constitutionalists ${ }^{11}$ to critical theorists ${ }^{12}$ to social scientists ${ }^{13}$ - that the ideas that laws attempt to embody or enforce harbor their own power, as aspirations towards our higher selves ${ }^{14}$ or as evidence of our limitations and fears. International lawyers know this perhaps best of all, as the salience of international legal rules as norms can precede or exceed their effectiveness as rules of positive law.

Labor of course particularly lends itself to this convergence/divergence analysis. Though international labor law, and most centrally the International Labor Organization, have occupied an historically primary role in establishing legal standards on the treatment of workers, over the postwar era and in particular in the late twentieth century's era of globalization, ${ }^{15}$ multiple regimes in other domains of international law have established rules and practices that significantly affect labor. The proliferation of international rules affecting labor has also created political and philosophical tensions: though an international trade perspective might view labor in purely economic terms, such a view is sharply limited by competing conceptions in the international legal order that emphasize the humanity and dignity of workers and that object to the commodification of labor. ${ }^{16}$

9. See, e.g., Migration AND InTERnAtional Legal NoRms (T. Alexander Aleinikoff \& Vincent Chetail eds., 2003); JOEL P. TRACHTMAN, THE INTERNATIONAL LAW OF ECONOMIC MigRation: TOWARD tHE FOURTH FREEDOM (2009); DAVID WEISSBRODT, THE HUMAN RightS OF NON-CITIZENS 36 (2008).

10. See infra Section II.F.

11. See, e.g., RONALD DWORKIN, A MATTER OF PRINCIPLE (1985).

12. See, e.g., Michel Foucault, THE ARChaEOlogy of KNowledge (A.M. Sheridan Smith trans., 2002).

13. See, e.g., Douglass NORTh, InStitutions, Institutional Change AND Economic PERFORMANCE (1990); ALEXANDER WENDT, SOCIAL THEORY OF INTERNATIONAL POLITICS (1999).

14. For treatments of the tension between natural conceptions of morality and justice and positivist rationality, see ALASDAIR MACINTYRE, AFTER VIRTUE (1981); JOSEPH RAZ, THE AUTHORITY OF LAW (1979).

15. See, e.g., Bob HePple, LaBor Laws AND Global TRADE 33 (2005).

16. E.g., INT'L LAB. ORG., DEClARATION OF PHILADELPHIA (1944) ("labor is not a commodity"). 
This essay will argue that even where disparate treaties converge doctrinally, they may diverge normatively and that normative divergence may be significant in its own right. Section II considers the normative implications of divergent rule systems. In particular, Section II raises the question of whether the rise of international criminal law, combating forms of illegal migration such as migrant smuggling and trafficking in persons, may support a normative divergence in international migration law between the primacy of the rights of individuals, on the one hand, and the primacy of states, on the other. This normative tension in turn marks a rift still greater than those between trade and labor, or labor and human rights: it represents the polarities of liberal legalism as a jurisprudential framework ultimately transcending sovereignty, or one that protects and legitimates sovereignty.

This kind of normative analysis is, of course, highly stylized. Legal regimes do not stand for only one set of norms, but rather reflect contested and complicated histories. International labor law, for example, harbors tensions between the "economic and the social," that is to say, an emphasis on particular industrial and workplace contexts versus broader aspirations toward justice. ${ }^{17}$ Moreover, even where particular principles predominate, this should not be taken to discount the importance of political economy, self-interested bargaining, and historical contingency in allowing those norms to prevail or in influencing the particular ways in which norms continue to develop and change over time.

Finally, a consideration of norms explicitly articulated by the treaties or laws in question does not begin to describe their full effect, and formal principles often create substantive effects sharply at odds with their own terms. The treaty regimes analyzed in this article should be studied not only in terms of their internal complexities but also in their external "realworld" impact. Such an analysis is beyond the scope of this essay. Nevertheless, by mapping the array of international legal regimes across human rights, trade, labor, and crime that affect migration, and in describing some of their prevalent doctrinal and normative characteristics, it is hoped that the article might contribute to emerging scholarship on this topic.

\section{DOCTRINAL CONVERGENCES AND DIVERGENCES}

The central principle in liberal legalism's self-understanding is formal equality, and it is reflected in international law's enshrinement of the doctrine of nondiscrimination. In international human rights law,

17. See, e.g., Adelle Blackett \& Colleen Sheppard, Collective Bargaining and Equality: Making Connections, 142 INT'L LAB. REV. 419 (2003). 
individuals are entitled to nondiscrimination by virtue of their irreducible equality as human beings; in international economic law, nondiscrimination arises from a commitment to the benefits of trade. In international labor law, individuals are entitled as workers to nondiscrimination in their enjoyment of protections that enable the pursuit of "material well-being... in conditions of freedom and dignity, of economic security and equal opportunity." 18 The precise contours of the right to nondiscrimination arise in these key areas: the right of territorial entry; ${ }^{19}$ the general right to nondiscrimination; ${ }^{20}$ the right to work and conditions of work; $;{ }^{21}$ freedoms of expression, association and assembly; ${ }^{22}$ and criminal due process. ${ }^{23}$

There are both convergences and divergences around the central principle of nondiscrimination, and particular aspects of it relevant to migrant workers' experiences, in the leading multilateral treaties. ${ }^{24}$ The remainder of this section proceeds in two stages: subsections $\mathrm{A}-\mathrm{E}$ provide a fairly close and relatively technical doctrinal exposition and analysis. This kind of detailed comparison across human rights, trade, labor, and crime recimes does not yet exist in the literature. Subsection $F$ then synthesizes and summarizes around doctrinal convergences and divergences concluding with a detailed examination of potential doctrinal conflicts.

- Human rights: In the area of human rights, the two 1964 Covenants, the International Covenant on Civil and Political Rights (ICCPR, or the "Civil and Political Covenant") ${ }^{25}$ and the International Covenant on Economic, Social and Cultural Rights (ICESCR, or "Economic Covenant") set forth standards on the principle of nondiscrimination generally, and also on particular aspects of worker rights.

Beyond these two general covenants, several specialized human rights treaties also. The 1965 International Convention on Elimination of Racial Discrimination (CERD or the "Racial

18. ILO, supra note 18.

19. See infra Section I.A.

20. See infra Section I.B.

21. See infra Section I.C.

22. See infra Section I.D.

23. See infra Section I.E.

24. International law is greatly complicated by the existence of regional and bilateral treaties, which are only occasionally addressed in this essay. In addition, the multilateral treaties themselves are subject to highly varying levels of ratification and assortments of reservations. Finally, of course, international norms are implemented differently within particular national legal systems. Thus, this exercise can do no more than offer an initial and instructive example of this analytical framework, hopefully demonstrating its utility. A fuller examination of the applicable transnational norms within any particular system is beyond the scope of this essay.

25. International Covenant on Civil and Political Rights, G.A. Res. 2200A (XXI), U.N. Doc. A/6316 (Dec. 16, 1966) [hereinafter Civil and Political Covenant]. 
Discrimination Convention") ${ }^{26}$ has weighed in on particular types of discrimination that can affect migrants. The 1951 Convention Relating to the Status of Refugees (the "Refugee Convention") $)^{27}$ set an important benchmark for the treatment of migrants fleeing political persecution. Most recently, the 1990 Convention on the Rights of Migrant Workers and Their Families (ICRMW or "Migrant Workers' Convention") addresses the plight of migrant workers specifically. ${ }^{28}$

- Labor: Predating human rights treaties are the treaties of the International Labor Organization, which include the Convention on the Freedom of Association and Protection of the Right to Organize, ${ }^{29}$ the Convention on the Right to Organize and Collective Bargaining ${ }^{30}$ the Convention on Discrimination, ${ }^{31}$ and the other "core" treaties recognized in the ILO's 1998 Declaration on Fundamental Principles and Rights at Work. ${ }^{32}$ The ILO has also adopted two specialized treaties on migrant workers, the 1949 Migration for Employment Convention, ${ }^{33}$ and the 1975 Migrant Workers (Supplementary Provisions) Convention. ${ }^{34}$

- Trade: The World Trade Organization (WTO), which is the 1995 successor to the General Agreement on Tariffs and Trade (GATT), includes the General Agreement on Trade in Services (GATS) ${ }^{35}$ GATS addresses labor as it relates to the provision of services by foreign nationals. Since the provision of services need not entail the movement of an actual person

26. General Recommendation XİV, Definition of Discrimination (22 Mar. 1993) U.N. Doc. A/48/18 (Mar. 22, 1993) [hereinafter Racial Discrimination Convention].

27. Convention Relating to the Status of Refugees art. 24(1), 189 U.N.T.S. 137 (July 28, 1951) [hereinafter Refugee Convention]

28. International Covenant on the Protection of the Rights of All Migrant Workers and Members of Their Families, G.A. Res. 45/158, Doc. A/RES/45/158 (Dec. 18, 1990) [hereinafter Migrant Workers ' Convention].

29. Freedom of Association and Protection of the Right to Organize Convention, July 9, 1948, 68 U.N.T.S. 17 (entered into force July 4, 1950).

30. Right to Organize and Collective Bargaining Convention, July 1, 1949, 96 U.N.T.S. 257 (entered into force July 18, 1951).

31. Discrimination (Employment and Occupation) Convention, June 25, 1958, 362 U.N.T.S. 31 (entered into force June 15, 1960).

32. ILO Declaration on Fundamental Principles and Rights at Work, June 18, 1998, 37 I.L.M. 1233 (1998)

33. Migration for Employment Convention (Revised), July 1, 1949, 120 U.N.T.S. 70 (entered into force Jan. 22, 1952) [hereinafter ILO Migration for Employment Convention].

34. Migrant Workers (Supplementary Provisions) Convention, June 24, 1965, 1120 U.N.T.S. 324 (entered into force Dec. 9, 1978) [hereinafter ILO Supplementary Provisions Convention].

35. General Agreement on Trade in Services, Apr. 15, 1994, Marrakesh Agreement Establishing the World Trade Organization, Annex 1B, 1869 U.N.T.S. 183, 33 I.L.M. 1167, 1187 (1994) [hereinafter GATS]. 
across a national border, not all categories, or "Modes," of GATS rules are relevant: within the GATS framework the most relevant is the framework addressing the Temporary Movement of Natural Persons ("Mode 4"). ${ }^{36}$

- Crime: In 2000, a new complex of multilateral agreements was negotiated at Palermo under the auspices of the Viennabased UN Office on Drugs and Crime Control: the Convention Against Transnational Organized Crime (the "Crime Convention") 37 and two Protocols, the "Migrant Smuggling Protocol" 38 and the "Trafficking in Persons Protocol., 39

Though the treaties listed above have varied structures and substantive orientations, they each potentially address the experience of the migrant worker, and can be examined on the basis of whether and how they permit differential treatment on the basis of citizenship status (i.e., non-citizen but documented) or documentary status (i.e., non-citizen and undocumented).

\section{A. Nondiscrimination in the Right of Territorial Entry}

Most labor rights relate to the experiences of workers who are actively employed in the state party in question, but there is the preliminary question of entering the territory. It is an enduring feature of modernity, and a generally-though not universally-accepted paradox ${ }^{40}$ that in a liberallegal world that champions the principle of nondiscrimination as foundational, the state nevertheless may make distinctions among persons seeking to enter its territory. ${ }^{41}$ International law generally reflects this normative commitment to sovereignty, so that there is no "right to immigrate. ${ }^{" 42}$ From a traditional perspective, the notion of a right to enter

36. GATS defines "Mode 4" as "the supply of a service by a service supplier of one Member, through presence of natural persons of a Member in the territory of any other Member." GATS, supra note 37 , art I, $\{2$ (d).

37. Convention against Transnational Organized Crime, G.A. Res. 55/25, Annex I, 55 U.N. Doc. A/45/49/Annex I (Nov. 15, 2000) [hereinafter Crime Convention].

38. Protocol Against the Smuggling of Migrants by Land, Sea and Air, Supplementing the United Nations Convention Against Transnational Crime, G.A. Res. 55/25, Annex III, U.N. Doc. A/45/49/Annex III (Nov. 15, 2000) [hereinafter Migrant-Smuggling Convention].

39. Protocol to Prevent, Suppress and Punish Trafficking in Persons, Especially Women and Children, Supplementing the United Nations Convention Against Transnational Organized Crime, G.A. Res. 25, Annex II, U.N. Doc. A/45/49/Annex II (Nov. 15, 2000) [hereinafter Trafficking Protocol].

40. See KeVIn R. JOHNSON, OPENING THE FloOdGATES: Why AMERICA NEEDS to RethINK ITS BORDERS AND IMMIGRATION LAWS (2007).

41. See infra Section II for further discussion of the normative.

42. Seyla Benhabib \& Judith Resnik, Introduction: Citizenship and Migration Theory Engendered, in MigRations AND MOBILITIES 1 (Seyla Benhabib \& Judith Resnik eds., 2009) (citing the Universal Declaration of Human Rights an example of foundational principles of contemporary international law, and noting that it does not specify a right to immigrate); TRACHTMAN, supra note 10, 
the territory of a sovereign state appears nonsensical, so deeply entrenched is the principle of territoriality as a feature of sovereignty. However, this basic recognition of sovereignty is not absolute. Exceptions in international law assert differing degrees of variance from the principle of sovereign territorial control.

The "strongest" exception to sovereign territorial control stems from international refugee law. Asylum seekers and refugees often enter the workforce and in some cases can contribute significantly to the migrant labor supply. ${ }^{43}$ For this reason, the central treaty to the international framework of refugee law, the Refugee Convention, provides refugees with both political and economic rights relevant to work. ${ }^{44}$ Because it addresses individuals who presumably find themselves in conditions of extreme duress, the Refugee Convention also effectively protects the right of territorial entry for asylum seekers, by requiring states to admit them at least on a temporary basis while refugee status determination takes place. ${ }^{45}$

Beyond this most assertive exception, in several cases international law recognizes the state's fundamental authority to screen immigrants, but constrains those procedures according to the principle of nondiscrimination. For example, although the Racial Discrimination Convention explicitly exempts from sanction the "distinction between citizens and noncitizens, ${ }^{, 46}$ the UN body responsible for interpreting the Convention has specifically invalidated racial discrimination in immigration criteria. ${ }^{47}$ The

at 172 ("Generally, of course, there is no obligation in customary international law or in human rights law to treat foreign persons as well as nationals in connection with admission") (emphasis in original).

43. For one case study of the overlap between asylum seeker and migrant worker populations, see

Chantal Thomas, Migrant Domestic Workers in Egypt, 58 AM. J. COMP. L. 987 (2010).

44. See infra I.C.

45. Refugee Convention, supra note 29, at art 31 ("Contracting States shall not impose penalties ... on refugees who, coming directly from a territory where their life or freedom was threatened ... enter or are present in a territory without authorization, provided they present themselves without delay to the authorities and show good cause for their illegal entry or presence." Interpretations by the Executive Committee of the UNHCR have further clarified that states have an obligation to admit asylum seekers at least on a temporary basis in order to adhere to the principle of non-refoulement. See U.N. HiGH COMMISSIONER FOR REFUGEES, EXCOM CONCLUSION NO. 6 ON NON-REFOULEMENT (1977) (reaffirming "the fundamental importance of the observance of the principle of non-refoulement-both at the border and within the territory of a State of persons who may be subjected to persecution if returned to their country of origin irrespective of whether or not they have been formally recognized as refugees"); U.N. HIGH COMMISSIONER FOR REFUGEES, EXCOM CONCLUSION NO. 8 ON DETERMINATION OF REFUGEE STATUS (1977) (laying out guidelines that would allow states to comply with the principle of non-refoulement, including the obligation to allow an asylum-seeker to remain in the territory at least temporarily while her refugee status is determined); U.N. HIGH COMMISSIONER FOR REFUGEES, EXCOM CONCLUSION NO. 22 ON THE CESSATION OF STATUS (1981) (reaffirming that even in cases of "largescale influx, asylum seekers should be admitted to the State in which they first seek refugee... at least on a temporary basis").

46. Racial Discrimination Convention, supra note 28, at art 1(2)). States Parties retain control over determining citizenship, as long as there is no discrimination against any particular nationality. Id. at art 1(3).

47. See id. I 2. See also David Weissbrodt, The Protection of Non-Citizens in International Human Rights Law, in INTERNATIONAL MigRation LAW: DEVELOPING PARAdigMS AND ChaLleNGES 
Human Rights Committee, which monitors the Civil and Political Covenant, recognizes the right of States' parties to decide "in principle" who enters their borders, ${ }^{48}$ has also recognized that the right of States to authorize territorial entry should be constrained by concerns of nondiscrimination. ${ }^{49}$

Whereas the human rights regimes more concerned with traditional civil and political equality have extended themselves to the issue of discrimination in immigration, those aspects of international law concerned with individual economic and social rights have demonstrated more deference. In some cases, such as the Economic Covenant, the position maintained is one of diplomatic silence. ${ }^{50}$ In the case of the labor rights conventions, both the UN Migrant Workers' Convention, and the ILO migrant labor conventions, reaffirm the state's prerogative over immigration $^{51}$ and exhort states to better enforce it so as to combat illegal immigration..$^{52}$

221, 225 (Ryszard Cholewinski, Richard Perruchoud \& Euan MacDonald eds., 2007); see Committee on the Elimination of Racial Discrimination, CERD/C/64/Misc.11/rev.3, Feb. 23-Mar. 12, 2004 ("xenophobia against non-nationals, particularly migrants, refugees and asylum-seekers, constitutes one of the main sources of contemporary racism . . . differential treatment based on citizenship or immigration status will constitute discrimination if the criteria for such differentiation, judged in the light of the objectives and purposes of the Convention, are not applied pursuant to a legitimate aim").

48. The Civil and Political Covenant "does not recognize the right of aliens to enter or to reside in the territory of a State party. It is in principle a matter for the State to decide who it will admit to its territory." Civil and Political Covenant, supra note 27. See Comment, Office of the High Commissioner of Human Rights, General Comment on the Position of Aliens Under the Covenant, Apr. 11, 1986, available at http://www.unhchr.ch/tbs/doc.nsf/0/bc561 aa8 Ibc5d86ec 12563ed004aaalb [hereinafter Position of Aliens].

A definitive discussion of the status of non-citizens under UN and regional human rights treaties is found in WEISSBRODT, supra note 3. Professor Weissbrodt was also the Special Rapporteur for the UN on the rights of non-citizens.

49. Position of Aliens, supra note 50. The Human Rights Committee only generally stated concerns of "non-discrimination, prohibition of inhuman treatment and respect for family life," but has declined to specify further.

Note that what is discussed in the text is only the right of territorial entry, not other issues related to territoriality such as acquisition of citizenship or residence authorization. For a detailed discussion of these issues, including the cases in which human rights bodies have allowed some forms of ethnic or linguistic discrimination, see WEISSBRODT, supra note 3.

50. WEISSBRODT, supra note 3, at 190 ("Unlike the Civil and Political Covenant, the Economic Covenant's monitoring body has not yet issued a comment clearly stating that the non-discrimination provision protects migrants.")

51. Migrant Workers' Convention, supra note 30, at art 35 ("Nothing in the present part of the Convention shall be interpreted as implying the regularization of the situation of migrant workers or members of their families who are non-documented or in an irregular situation or any right to such regularization of their situation").

52. Id. at art. 68 ("States Parties, including States of transit, shall collaborate with a view to preventing and eliminating illegal or clandestine movements and employment of migrant workers in an irregular situation."); ILO Supplementary Provisions Convention, supra note 36, at art. 3 (requiring states to "suppress clandestine movements of migrants for employment"). Indeed the ILO Convention goes so far as to call for greater enforcement of border control (id. at Art 2, requiring each signatory to "determine whether there are illegally employed migrant workers on its territory"; $I d$. at art. 3, requiring signatories to adopt measures to "suppress clandestine movements of migrants for employment and illegal employment of migrants"; $I d$. at art. 6 ("Provision shall be made under national laws or 
The basis for this divergence between civil and political rights, and economic and social rights, stems from differences in surrounding context and rationale. In the case of the latter, considerations of political will and the need to avoid the treaty's rejection by antisocialist states may have informed the greater deference. In addition to this essentially negative reason, however, lies both the positive concern for the well-being of all workers, and the desire to avoid the erosion of some workers' bargaining power through the presence of others more easily exploitable..$^{53}$

Coming to international trade, the World Trade Organization does generally reserve to members the right to "regulate the entry" of workers who would otherwise be covered under the General Agreement on Trade in Services, in the GATS Annex on the Movement of Natural Persons. ${ }^{54}$ For workers who are employed in temporary contracts under sectors that Members have included in their specific commitments, Members can regulate entry only provided that such regulation does not "nullify or impair the benefits" accorded by that commitment. ${ }^{55}$ That is, if particular sectors have been included under GATS's other commitments, workers "shall be allowed to provide" those services and any entry regulations would not be permitted to bar them from doing so. ${ }^{56}$ This obligation still generally preserves the territorial sovereignty of Members: it just means that they

regulations for the effective detection of the illegal employment of migrant workers and for the definition and the application of administrative, civil and penal sanctions")).

53. Awareness of the negative effect of differences in labor standards on the preservation of labor standards-in other words, the danger of a "race to the bottom" driven by competition-has appeared with regularity in the history and text of the ILO. See, e.g., NICOLAS VALTICOS, INTERNATIONAL LABOUR LAW 20 (1979) ("One of the oldest ideas advanced in favor of international conventions in the field of labour was that of international competition... international agreements in the field of labour would avoid international competition from taking place to the disadvantage of workers, by a kind of inhuman 'dumping."'). The importance of uniform minimum standards below which labor markets cannot go is reflected in the 1919 ILO constitution ("the failure of any nation to adopt human conditions of labour is an obstacle in the way of other nations which desire to improve the conditions in their own countries" and in the 1944 ILO Declaration of Philadelphia ("poverty anywhere constitutes a danger to prosperity everywhere."). The ILO's position on competition modified over the years toward an endorsement of "constructive competition." See BOB HEPPLE, LABOR LAWS AND GLOBAL TRADE 33 (2005) (explaining that the "argument for international standards as a means of regularing competition" was more prominent in the ILO's founding than in subsequent eras). Nevertheless, even in this more moderate context international standards are deemed important in "preventing destructive competition." Id. (emphasis added). Although the Migration for Employment Convention addresses workers of disparate nationalities in a single market, as opposed to workers across disparate nations, a similar logic would seem to apply.

54. General Agreement on Trade in Services, Apr. 15, 1994, Marrakesh Agreement Establishing the World Trade Organization, Annex on Movement of Natural Persons Supplying Services Under the Agreement, 1869 U.N.T.S. 183, 33 I.L.M. 1167, 1187 (1994) [hereinafter MONP Annex], If 4.

55. See id:; see also TRACHTMAN, supra note 10, at 247.

56. Joel Trachtman interprets the MONP Annex to establish a higher standard than only "does not nullify or impair"; he would also add a "necessity test" i.e. that the entry regulation would need to be necessary which has been interpreted to mean the least possible trade restrictive. TRACHTMAN, supra note 10, at 244 (considering past WTO jurisprudence). 
cannot give commitments under the schedules but then take them away with onerous entry requirements.

The GATS does recognize the WTO's general requirement of nondiscrimination among Members (the "most-favored nation principle"). However, it also specifies that Members can, at the least, impose differential visa requirements for nationals of different Members. ${ }^{57}$ Whereas treaty bodies have interpreted international civil and political rights to bar discrimination in immigration criteria, the trade law of the GATS would appear to establish a weaker non-discrimination constraint, albeit one that at least theoretically could apply to any non-visa immigration requirements that differentiate on the basis of nationality.

In addition to these explicit constraints on the sovereign prerogative of territorial control, international law has created an implicit, but ultimately more powerful, constraint in some cases by decoupling the right to authorize entry with the rights enjoyed by workers once in a state's territory. In some cases, the fact of unlawful entry or residence does not necessarily deprive migrant workers of certain rights under international law, as is discussed in the next sections.

\section{B. The General Right to Nondiscrimination}

Once migrants have entered the territory, there are several specific categories of enumerated rights that are relevant to their experiences as workers: there are the civil and political rights related to trade union organizing; economic and social rights related to minimum standards and conditions of work; and criminal process rights. These are discussed below in turn, and treaties vary in their substantive expressions in each of these categories. Apart from these more specific rights, however, there is the general question of the scope of nondiscrimination as a general, catchall principle applying to migrant workers.

In the area of human rights, both the Civil and Political Covenant, and the Economic Covenant, recognize the general right of all human beings to nondiscrimination without distinction based on national origin, birth or "other status." 58 The Human Rights Committee has clarified that "other status" in the Civil and Political Covenant includes the distinction between

57. See MONP Annex, supra note 56, at $\mathbf{n} .1$ ("the sole fact of requiring a visa for natural persons of certain Members and not for those of others shall not be regarded as nullifying or impairing benefits under" GATS obligations). In addition, Members appear to retain total control over measures specifying residence and permanent employment requirements, as well as over workers who are seeking employment rather than already employed. $I d .113$.

58. International Covenant on Economic, Social and Cultural Rights, G.A. Res. 2200A (XXI) (Dec. 16, 1966), at art. 2(2) [hereinafter Economic Covenant]; Civil and Political Covenant, supra note 27 , at arts. 2(1) \& 26 . 
citizens and aliens ${ }^{59}$ with only a narrow exception for the right to vote. ${ }^{60}$ Moreover, this equality extends to undocumented immigrants as well, according to the Committee, with only one exception of the right to freedom of movement. ${ }^{61}$ As with the right of entry described above, the Economic Covenant is much more circumspect: the UN Committee on Economic, Social and Cultural Rights has declined to comment on the application of the Economic Covenant rights to non-nationals more generally. Moreover, the treaty explicitly grants developing countries the right to exclude non-nationals. ${ }^{62}$

In the case of the Migrant Workers' Convention, the question of nondiscrimination between citizens and aliens does not arise because, by definition of its scope, the Convention applies only to aliens. The question then is whether there may be discrimination among classes of aliens. The same term that exists in the Covenants, "other status," is used to define the Convention's scope of application of the Migrant Workers' Convention, but with the important qualification "except as otherwise provided hereafter,"63 and the "hereafter" in question clearly demarcates rights into those that apply to all workers regardless of documentary status, ${ }^{64}$ and those that

59. General Comment 15 on the Position of Aliens under the Covenant (Apr. 11, 1986), I 1, reproduced in UN Doc. HRI/GEN/1/Rev.1. The Comment states that "the general rule is that each one of the rights of the Covenant must be guaranteed without discrimination between citizens and aliens [but] ... the Committee's experience in examining reports shows that in a number of countries ... rights that aliens should enjoy under the Covenant are denied to them or are subject to limitations that cannot always be justified under the Covenant." ("Reports from States have often failed to take into account that each State party must ensure the rights in the Covenant to 'all individuals within its territory and subject to its jurisdiction' (art.2(1)). In general, the rights set forth in the Covenant apply to everyone, irrespective of reciprocity, and irrespective of his or her nationality or statelessness."). Id.

60. David Weissbrodt, The Protection of Non-Citizens in International Human Rights Law, in International Migration law: Developing Paradigms and Challenges 224 (Ryszard Cholewinski, Richard Perruchoud \& Euan MacDonald eds., 2007). Although this principle is sweepingly stated, several commentators have observed that more could be done to enunciate its content. See id. at 233; T. Alexander Aleinikoff, International Legal Norms on Migration: Substance without Architecture, in INTERNATIONAL MIGRATION LAW: DEVELOPING PARADIGMS AND Challenges 469 (Ryszard Cholewinski, Richard Perruchoud \& Euan MacDonald eds., 2007).

61. General Comment 15 states that "[o]nce an alien is lawfully within a territory, his freedom of movement within the territory and his right to leave that territory may only be restricted in accordance with article 12(3)." Since this is the only place where lawful status is explicitly mentioned, one can be even more confident in interpreting the lack of explicit mention as intentional. This would support the application of the nondiscrimination principle regardless of lawful status. The familiar canon of legal interpretation, exclusio unio inclusio alterius can be applied to conclude that the fact that lawful status is mentioned here but not elsewhere suggests that with respect to the other principles, lawful status is not a basis for distinction. This interpretation is supported by David Weissbrodt, The Protection of NonCitizens in International Human Rights Law, in INTERNATIONAL MIGRATION LAW: DEVELOPING Paradigms AND Challenges 224 (Ryszard Cholewinski, Richard Perruchoud, \& Euan MacDonald eds., 2007) ("The ICCPR contains a narrow exception to...equality for non-citizens with respect to ... the right to vote; and freedom of movement ... which may be denied to undocumented immigrants").

62. Economic Covenant, supra note 60, at art 2(3).

63. Migrant Workers' Convention, supra note 30, at Art 1.

64. Id. Part III. 
apply to migrant workers who are "documented or in a regular situation." 65 Although there is a separate sub-section preceding the lists of substantive rights that exists solely to set forth a general non-discrimination commitment, ${ }^{66}$ that general principle cannot apply to documentary status given the treaty's allocation of substantive rights explicitly on the basis of documentary status. ${ }^{67}$ The "rights provided for in the present Convention"68 do distinguish between documented and undocumented workers, providing to the documented workers rights relating to access to educational, vocational, housing, and health institutions and services, as well as certain labor protections. ${ }^{69}$

The Racial Discrimination Convention asserts a sweeping nondiscrimination provision including "other status" and does, as interpreted by the treaty body, apply to immigration and citizenship criteria linked to race, descent, or national origin. ${ }^{70}$ If there is no discrimination on this sort of identity basis, however, the Convention explicitly backs off of the distinction between citizens and aliens. ${ }^{71}$

Again, there is convergence and divergence with apparently an underlying political trade-off in each of these treaties on human rights. The most far-reaching of the treaties is the Civil and Political Covenant. The Racial Discrimination Convention stops short of the line that the Civil and Political Covenant draws, perhaps trading off more explicit commitments on the sensitive issues of race and ethnicity for another mode of "outgroup" discrimination against non-citizens more generally. The Economic Covenant, with its yet more controversial orientation toward economically redistributive justice, expresses more deference still to sovereign prerogatives over citizenship and its exclusiveness.

Within international trade law, the norm of nondiscrimination is expressed in two key principles: that of most-favored nation treatment, which requires states parties to treat nationals of all other states parties equally; and that of national treatment, which requires a state party to forego preferential treatment of its own nationals. In its jurisprudence related to trade in goods, the WTO's interpretation of the nondiscrimination norm has been strikingly expansive, with much more liberal approaches to proving discrimination than, for example, would be the case in U.S.

65. Id. Part IV.

66. Id. Part II.

67. See infra Section II.C. for more detail on which rights are provided to documented and which to undocumented workers.

68. Migrant Workers' Convention, supra note 30, at art. 7

69. Id. at art 43 .

70. Racial Discrimination Convention, supra note 28 , at art. I(1).

71. Id. at art I(2) ("This Convention shall not apply to distinctions, exclusions, restrictions or preferences made by a State Party ... between citizens and non-citizens."). 
constitutional law. The breadth of these principles perhaps explains why their initial scope was rather limited, to tariffs and other technical "border" measures affecting trade, and expanded only after several decades. Indeed, the GATS, with its application to labor, was enacted only in 1994 with the succession by the World Trade Organization of the original General Agreement on Tariffs and Trade.

Reflecting this particular balancing dynamic, the GATS retains the broad statements of most-favored nation treatment and national treatment. Although, the general most-favored nation treatment principle applies with only a few exemptions to trade in services, ${ }^{72}$ the more politically and economically sensitive national treatment principle (which entails competition between nationals and foreigners) applies only to those sectors falling specifically within states parties' specific commitments. These commitments can be quite specific indeed, so that states retain virtually complete control over their exposure. Once the specific commitment has been made, the principle of national treatment applies in its broad form within that constraint.

The ILO Migration for Employment Convention and Supplementary Provisions Convention make no generalized call for nondiscrimination, beyond the latter's reminder of the obligation of states parties to "respect the basic human rights of all migrant workers." 73 Apart from this, the principle of nondiscrimination as stated in these is limited to particular and listed rights related to the workplace, ${ }^{74}$ as opposed to the generalized language that exists in the human rights treaties. Moreover, the ILO rights are once again carefully limited to lawful workers only, ${ }^{75}$ removing the question of extending worker rights to irregular migrants with the key exception of terms and conditions of work "arising out of past employment." $" 76$ This exception is important because it indicates the ILO sensibility: on the one hand, more pragmatic and deferential to states' ability to determine the right to enter; and on the other hand, with a focus on equalizing bargaining power across workers. ${ }^{77}$ This carefully limited right to nondiscrimination may be at odds, however, with the broader language of ILO's Convention on Discrimination. ${ }^{78}$

72. See Julia Nielsen \& Daria TAglioni, A Quick Guide to the GATS AND Mode 4 (2003).

73. ILO Supplementary Provisions Convention, supra note 36, at art 1(1).

74. See id.

75. Ryszard Cholewinski, The Rights of Migrant Workers, in INTERNATIONAL MIGRATION LAw: Developing Paradigms and Challenges 258 (Ryszard Cholewinski, Richard Perruchoud \& Euan MacDonald eds., 2007).

76. ILO Supplementary Provisions Convention, supra note 36, at art 9(1).

77. See supra note 57.

78. The ILO Convention on Discrimination defines "discrimination" to include any distinction "on the basis of race, colour, sex, religion, political opinion, national extraction or social origin." art. 1(a). The Convention also, however, accords to the state the right to determine any further extension of its 


\section{Nondiscrimination in the Right to Work and Conditions of Work}

The Refugee Convention requires that refugees enjoy equality with nationals regarding both to the right to work, and to labor legislation and social security provisions. ${ }^{79}$ In terms of the actual conditions of the workplace, it is not surprising that the human rights treaties differ in their level of specificity. The Civil and Political Covenant, which has the broadest purview in terms of nondiscrimination, does not include economic rights such as the right to work and to minimum standards in workplace terms and conditions. The Economic Covenant recognizes the right to work, ${ }^{80}$ and to "just and favourable conditions of work", ${ }^{81}$ developing countries are not required to extend this to non-nationals, however, and in any case the scope of these basic rights has not been specified in cases where they would apply. ${ }^{82}$

As for the other treaties dealing with labor rights, convergence appears on the principle that, regardless of states' obligations to non-nationals, once an employment relationship is initiated no discriminatory treatment of migrant workers should be permitted. This principle of equality for actual employment relations regardless of lawfulness is reflected in the Migrant Workers' Convention. ${ }^{83}$ The Convention does otherwise distinguish in the substantive economic rights granted to migrant workers on the basis of documentary status, guaranteeing to undocumented workers only the right to emergency medical care ${ }^{84}$ and the transferability of earnings upon termination of employment, ${ }^{85}$ whereas documented workers enjoy an

scope. art. 1(b) ("Such other distinction ... may be determined by the Member"). Nevertheless, particularly subsequent to the enshrinement of nondiscrimination as a "core" labor right in the 1998 Declaration on Fundamental Rights and Principles at Work, the ILO right to nondiscrimination is understood to be of general application. For a discussion of the implications of this broad interpretive scope, see Blackett \& Sheppard, supra note 19, at 419.

79. See Refugee Convention, supra note 29 , at arts. $17 \& 24$.

80. Economic Covenant, supra note 60 , at art. 6(1) ("States Parties . . . recognize the right to work").

81. Id. at art 7 .

82. See id at art. 2(3).

83. The Migrant Workers' Convention grants treatment not less favorable than nationals with respect to remuneration, "conditions of work" ("overtime, hours of work, weekly rest, holidays with pay, safety, health, termination of the employment relationship"), other "terms of employment" ("minimum age of employment"). Migrant Workers' Convention, supra note 30, at art. 25. Moreover, states parties "shall take all appropriate measures to ensure that migrant workers are not deprived of any rights derived from this principle by reason of any irregularity in their stay or employment. In particular, employers shall not be relieved of any legal or contractual obligations, nor shall their obligations be limited in any manner by reason of such irregularity."

84. Migrant Workers' Convention, supra note 30, at art. 28.

85. Id. at art 32. Although the Convention does contain a provision on social security for undocumented workers, $i d$. at art. 27 , it is nonbinding, stating only that social security may be granted as long as provided for by law of state party; if state party does not allow, then Convention requests state party to "examine the possibility of" reimbursement. 
ongoing right to transfer earnings and savings ${ }^{86}$ and treatment no less favorable than nationals in terms of taxation, ${ }^{87}$ and unemployment benefits. $^{88}$ Thus, even though states essentially maintain total control over determining the terms on which migrant workers may enter, what kinds of employment they may seek, and for how long, ${ }^{89}$ because the equality principle attaches upon employment, the Migrant Workers' Convention can be said to guarantee "basic economic, social and cultural rights to both regular and irregular migrant workers." 90

The ILO also reflects the norm that, though in principle states parties retain the right to distinguish between documented and undocumented migrant workers, with only the former receiving guarantees of equal treatment a priori, ${ }^{91}$ all workers are entitled to equal treatment regarding past employment. Indeed, in this respect, the ILO exceeds the Migrant Workers' Convention by including social security in this exception. ${ }^{92}$

The ILO places another notable constraint on the state's authorization of workers, by providing an automatic regularization for workers after a period of not more than two years. ${ }^{93}$ The ILO's final gesture in the direction of equality is to exhort, but not require, states parties "to pursue a national policy designed to promote and to guarantee... equality of opportunity and treatment in respect of employment and occupation, of

86. Id. at art 47 .

87. Id. at art. 48

88. Id. at art. 54

89. Id. at art. 52.

90. Ryszard Cholewinski, The Rights of Migrant Workers, in INTERNATIONAL MIGRATION LAw: Developing Paradigms and Challenges 259 (Ryszard Cholewinski, Richard Perruchoud \& Euan MacDonald eds., 2007).

91. ILO Migration for Employment Convention, supra note 35, at art $6(1)(\mathrm{a})(\mathrm{i})$, (b), (c) (nondiscrimination with respect to remuneration and conditions of work, social security and taxes). Nondiscrimination in work conditions is for lawful workers only (with exclusion of only a few particular categories; see id. at art. 11 (excluding "frontier workers, short-term entry of members of the liberal professions and artistes, and seamen"; see also ILO Supplementary Provisions Convention, supra note 36 , at art 11 .

92. ILO Supplementary Provisions Convention, supra note 36, at art 9(1).

Without prejudice to measures designed to control movements of migrants for employment by ensuring that migrant workers enter national territory and are admitted to employment in conformity with the relevant laws and regulations, the migrant worker shall, in cases in which these laws and regulations have not been respected and in which his position cannot be regularized, enjoy equality of treatment for himself and his family in respect of rights arising out of past employment as regards remuneration, social security and other benefits.

93. The ILO Supplementary Provisions Convention does provide the right to work without constraint after "a prescribed period of up to two years of lawful residence or, if the laws or regulations of the State Party only provide for fixed-term contracts of less than two years, after completion of the first work contract." Ryszard Cholewinski, The Rights of Migrant Workers, in INTERNATIONAL Migration Law: Developing Paradigms and Challenges 258 (Ryszard Cholewinski, Richard Perruchoud \& Euan MacDonald eds., 2007). 
social security, of trade union and cultural rights and of individual and collective freedoms." ${ }^{\circ 4}$

In international trade law, the GATS system of specific commitments places no automatic obligation on states to provide the right to work or to meet any minimum standards in terms of workplace conditions. However, there is the general most-favored nation treatment rule and also, within specific commitments, the requirement of nondiscrimination in the form of national treatment. States have the ability to list exceptions in schedules, and many states use wage parity tests and economic needs tests before permitting employment of foreign nationals. ${ }^{95}$

Rather than setting constraints on labor rights, the GATS expresses nondiscrimination in terms of the regulation of trade flows: its market access obligation for specific commitments bars the prohibition of services by foreign nationals on the basis of quantitative restrictions such as number of employees or market value of services provided. ${ }^{96}$ Because this obligation applies only to specific commitments, however, states are free to maintain such restrictions as long as they do not commit to do otherwise, and indeed such restrictions are common. ${ }^{97}$

For those services that are listed as specific commitments, the question arises as to whether qualification and licensing requirements might constitute disguised protectionism. GATS requires that any such domestic regulations be applied in a "reasonable, objective and impartial" manner. This is further indicated to mean "not more burdensome than necessary," unless that burden could not have reasonably been anticipated at the time the specific commitments were made. ${ }^{98}$ Although earlier trade law jurisprudence applied a relatively strict interpretation of this "necessity test," to mean the least trade-restrictive possible measure, more recent decisions by the WTO Appellate Body have softened this approach, balancing the consideration of necessity against other considerations such as "the importance of the common interests or values protected by that law or regulation, and the accompanying impact of the law or regulation on imports or exports." 99

94. ILO Supplementary Provisions Convention, supra note 36.

95. TRACHTMAN, supra note 10 , at 250 . The MONP Annex allows states to "regulate entry" as long as no "nullification and impairment" which has been interpreted by some to mean "necessity test" with regards to temporary workers; to date these requirements have not been challenged as impermissible under these constraints.

96. GATS, supra note 37, at Art XVI.

97. For example, the United States maintains numerical limits on business visas within its H1-B and $L 1$ programs.

98. GATS, supra note 37, at Art VI:1.

99. Trachtman has noted that the necessity test as applied elsewhere in GATT/WTO has been interpreted to mean the least trade restrictive possible, (Trachtman 261) though other more recent decisions (such as the $\mathrm{AB}$ reports in EC Asbestos and Korea-Beef) set forth a balancing test that also 
The de jure framework for services, then, remains consistent with the broad principle of nondiscrimination cabined by the pragmatic recognition of states' ability to tailor that commitment. In addition to this de jure framework, it should also be observed that, de facto, the specific commitments that states have made tilt strongly toward professional services. $^{100}$

\section{Nondiscrimination in Freedom of Expression, Association, and Assembly}

The Civil and Political Covenant establishes that "[e]veryone shall have the right to freedom of association with others, including the right to form and join trade unions for the protection of interests." time, this right is subject to "restrictions ... prescribed by law and necessary in a democratic society in the interests of national security or public safety, public order, the protection of public health or morals or the protection of the rights and freedoms of others."102 Though such restrictions might include those distinguishing documented from undocumented workers, the prevailing interpretation of the Covenant based on the statements of the Human Rights Committee is that a distinction on the basis of documentary status would not hold. ${ }^{103}$

Based on this interpretation, the Migrant Workers' Convention accords a level of protection somewhat lower than that found in the Civil and Political Covenant: whereas documented workers may form and participate in trade unions and exercise all attendant rights of expression, association, and assembly, undocumented workers are not provided the right to form associations, ${ }^{104}$ only to take part in them. ${ }^{105}$ Hence, although "most of the civil and political rights found in other more general human rights instruments apply to all persons, including migrant workers . . . irrespective of legal status," 106 the ability of undocumented migrant workers to form

\footnotetext{
requires a "proportionality" type of analysis, considering "the importance of the common interests or values protected by that law or regulation, and the accompanying impact of the law or regulation on imports or exports." Appellate Body Report, Korea-Measures Affecting Imports of Fresh, Chilled and Frozen Beef, WT/DS161/AB/R (Dec. 11, 2000).

100. Antonia Carzaniga, GATS, Mode 4 and the Pattern of Commitments, in Moving PEOPLE TO DELIVER SER VICES (Aaditya Mattoo \& Antonia Carzaniga eds., 2003). For Mode 4 commitments, 93\% of commitments are for high-skilled labor: $23 \%$ for business visitors, $28 \%$ for executives, managers or specialists, $42 \%$ for employees transferring between branches of corporation.

101. Civil and Political Covenant, supra note 27, at art. 22(1)

102. Id. at art. 22(2).

103. See id.

104. Migrant Workers' Convention, supra note 30, at art 40.

105. Id. at art 26.

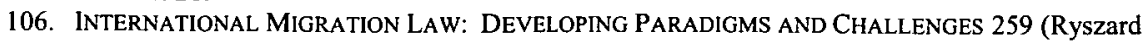
Cholewinski, Richard Perruchoud \& Euan MacDonald eds., 2007).
} 
their own trade unions is not protected under international human rights law.

The ILO has been still more circumspect in its explicit treatment of migrant workers: the Migration for Employment Convention requires states parties to allow only to lawful workers "membership of trade unions and enjoyment of the benefits of collective bargaining." 107 Thus, undocumented migrant workers enjoy the right to participate in, but not form, trade unions under the Migrant Workers' Convention, but are not granted any such right under the ILO Migration for Employment Convention.

On the other hand, the ILO Freedom of Association Convention applies, on its own terms, "without distinction whatsoever"; and the Collective Bargaining Convention requires "adequate protection against acts of anti-union discrimination." The ILO's treatment of specific cases involving the organizing rights of undocumented migrant workers has suggested that they do enjoy rights under these latter conventions, which are also held by the ILO to apply to all ILO members and not just signatory states. $^{108}$

\section{E. Criminal Due Process}

Although rights of criminal due process would not appear immediately relevant to the migrant worker experience specifically, the often precarious social position of migrants in some contexts renders the topic worthy of consideration. This is particularly true in the case of undocumented migrant workers, as well as asylum seekers, who are much more subject to the threat of arrest, detention and deportation. ${ }^{109}$

The Civil and Political Covenant establishes a basic norm of nondiscrimination in criminal process through its provision that "All persons shall be equal before the courts and tribunals." 110 In addition, though, minimum standards are laid out in the context of criminal due process. These include the right to life and freedom from arbitrary deprivation of life, ${ }^{111}$ freedom from torture, ${ }^{112}$ freedom from slavery of various forms, ${ }^{113}$ freedom from arbitrary arrest, ${ }^{114}$ and the right to a fair and

107. ILO Migration for Employment Convention, supra note 35, at art 6(1)(a)(ii).

108. See infra Section I.F.

109. Shyla Vohra, Detention of Irregular Migrants and Asylum-Seekers, in INTERNATIONAL Migration Law: Developing ParadigMS and Challenges 49 (Ryszard Cholewinski, Richard Perruchoud \& Euan MacDonald eds., 2007).

110. Civil and Political Covenant, supra note 27, at art 14(1).

111. Id. at art 6.

112. Id. at art 7 .

113. Id. at art 8 (prohibiting slavery and servitude).

114. Id. at art 9 . 
public hearing without undue delay. ${ }^{115}$ The Migrant Workers' Convention largely reflects the norms established in the Civil and Political Covenant, with the striking exception that the provision of the right to life is not accompanied by language forbidding arbitrary deprivation of life. ${ }^{116}$

Of all the treaties under consideration here, only the Civil and Political Covenant and the Migrant Workers' Convention explicitly establish protections for criminal due process, although the Refugee Convention more generally does guarantee "free access" and national treatment for refugees with respect to the court system.

This is perhaps not surprising with respect to the treaties explicitly aimed toward economic ends, such as the ILO Conventions or the trade agreements. It is perhaps more surprising that the Crime Convention and its accompanying Protocols are silent as to internationally recognized minimum standards for criminal due process.

The Crime Convention requires member states to criminalize participation in a criminal group, money laundering, corruption of public officials, and obstruction of justice; 117 the Migrant Smuggling Protocol requires member states to criminalize the transport of migrants without valid travel documentation, and related uses of fraudulent travel documents; ${ }^{118}$ the Trafficking Protocol requires member states to criminalize the "trafficking of persons" as defined in the Protocol. 119

115. Id. at arts $9 \& 14$.

116. Migrant Workers' Convention, supra note 30, at art. 9. Instead, the Convention provides that the right to life shall be "protected by law."

117. Crime Convention, supra note 39, at art. 5 (establishing as an offense the act of "[a]greeing with one or more other persons to commit a serious crime for a purpose relating directly or indirectly to the obtaining of a financial or other material benefit and, where required by domestic law, involving an act undertaken by one of the participants in furtherance of the agreement or involving an organized criminal group"; the "action" requirement is a consequence of the nonrecognition of the crime of conspiracy in the civil law system); id. at art. 6 (establishing as an offense the "conversion or transfer of property, knowing that such property is the proceeds of crime, for the purpose of concealing or disguising the illicit origin of the property"); $i d$. at art. 8 (establishing as an offense the "promise, offering or giving to a public official" or "solicitation or acceptance by a public official," "directly or indirectly, of an undue advantage, for the official himself or herself or another person or entity, in order that the official act or refrain from acting in the exercise of his or her official duties"); Obstruction of justice: Organized Crime Convention, art. 23 (establishing as a criminal offense, when committed intentionally, "the use of physical force, threats or intimidation or the . . offering . . of an undue advantage to induce false testimony or to interfere in the giving of testimony or the production of evidence" or to otherwise "to interfere with the exercise of official duties by a justice or law enforcement official" in a proceeding in relation to the commission of offences covered by this Convention" or otherwise to).

118. See Migrant Smuggling Protocol, supra note 40, at art. 6 (establishing as a criminal offense, "when committed intentionally and in order to obtain, directly or indirectly, a financial or other material benefit," smuggling of migrants, or producing, providing, procuring or possessing a fraudulent travel or identity document when such acts "committed for the purpose of enabling the smuggling of migrants.

119. See Trafficking Protocol, supra note 41, at art. 5: requires criminalization of trafficking, as defined in art. 3 :

the recruitment, transportation, transfer, harbouring or receipt of persons, by means of the threat or use of force or other forms of coercion, of abduction, of fraud, of deception, of 
The Crime Convention itself makes mention only of the domestic criminal laws of states parties, and not of international standards. ${ }^{120}$ The accompanying Protocols on trafficking in persons and the smuggling of migrants, however, do contain "saving" clauses, which provide that nothing in the Protocols affects the rights and obligations of states under other treaties. ${ }^{121}$ Although these instruments require that the state establish criminal procedures for particular offenses, however, they do not instruct states to abide by any minimum standards as far as the fairness of those procedures.

\section{F. Doctrinal Relationships Between the Treaties}

Viewing these treaties from the perspective of their treatment of migrant workers, doctrinal convergences and divergences appear around the central principle of nondiscrimination. In general, the human rights, trade, and labor treaties emphasize the normative importance of the principle, articulating it in several contexts. Within the human rights treaties, the more general agreements (e.g., the Civil and Political Covenant) seem to extend the principle further than the agreement specific to migrant workers, the UN Migrant Workers' Convention, which more explicitly differentiates the rights enjoyed by documented as opposed to undocumented workers. The ILO agreements appear much more deferential to state territorial control, with the important exception that, regardless of states' obligations to non-nationals, once an employment relationship is initiated no discriminatory treatment of migrant workers should be permitted.

The trade agreement, the GATS, states the principle of nondiscrimination forcefully as a general matter, in its provisions on mostfavored nation treatment and non-discrimination, but limits that principle sharply in explicit application. Mode 4 applies only to temporary workers,

the abuse of power or of a position of vulnerability or of the giving or receiving of payments or benefits to achieve the consent of a person having control over another person, for the purpose of exploitation. Exploitation shall include, at a minimum, the exploitation of the prostitution of others or other forms of sexual exploitation, forced labour or services, slavery or practices similar to slavery, servitude or the removal of organs.

The Protocol specifies "the consent of a victim of trafficking in persons to the intended exploitation [as defined in the Protocol] shall be irrelevant where any of the means set forth in [the Protocol] have been used." The definition of trafficking in the Protocol has been very controversial, particularly within communities of feminist theorists and women's rights advocates. See Chantal Thomas, Manuscript, A Critical Perspective on the International Law Against Trafficking in Persons (2002).

120. The one exception to this is a reference to international norms on the establishment of jurisdiction. See Crime Convention, supra note 39, at art 15(6) ("Without prejudice to norms of general international law, this Convention does not exclude the exercise of any criminal jurisdiction established by a State Party in accordance with its domestic law").

121. Migrant Smuggling Protocol, supra note 40, at art 19; Trafficking Protocol, supra note 41, at art 14. 
reserving to the state the right to determine conditions of permanent residence and employment. Within Mode 4, states have complete discretion as to which sectors of labor will be subject to GATS constraints. Limitations on Mode 4 are largely the product of political economy-they tend to represent areas in which government representatives determine that some subset of interest groups influencing state behavior wishes to continue policies of discrimination on the basis of national origin.

Considering these treaties in terms of the total effect of their statements of principle and their reservation of exceptions, patterns of convergence and divergence can be observed as represented graphically in the chart on the next page:

\section{Explicit Rights and Equalities Across Treaty Categories}
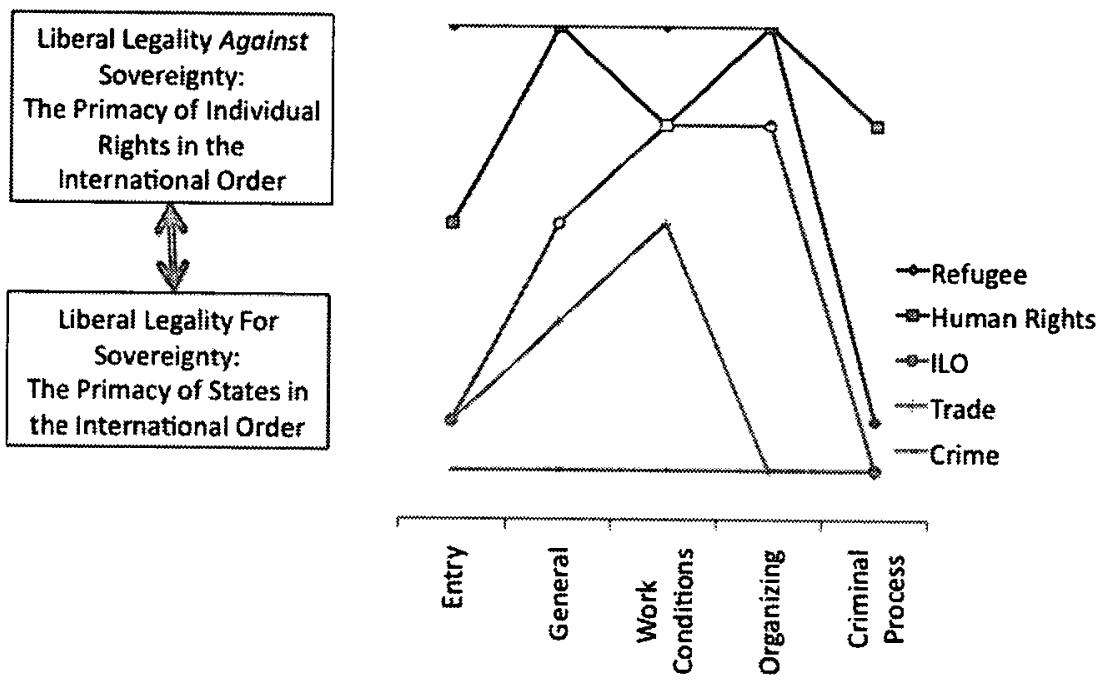

This chart graphically renders the convergences and divergences in international legal norms affecting migrant workers. Although international law may be converging around a general set of principles or a "bill of rights" for migrant workers, ${ }^{122}$ some differences are clearly visible. Those differences can broadly be understood as the product of the tension between a worldview of international law that envisions states as the primary actors,

122. T. Alexander Aleinikoff, International Legal Norms on Migration: Substance without

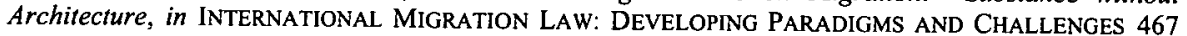
(Ryszard Cholewinski, Richard Perruchoud \& Euan MacDonald eds., 2007). 
with ultimate sovereignty in discretion over territorial control on the one hand, and a worldview that sees the rights of individuals as primary.

Within that general tension, further differences appear according to the particularities of each treaty system. The labor conventions, for example, peak in their emphasis on individual rights within the issue areas of conditions of work and the right to organize. The trade agreement, despite the normative clarity of the most-favored nation and national treatment principles, remains largely deferential, but peaks in its assertiveness with respect to conditions of work, as discrimination in that area is most naturally seen as a constraint on conditions of competition in line with economic concerns. The Refugee Convention states the principle of nondiscrimination more strongly than its counterparts with respect to the right to territorial entry, in keeping with that convention's emphasis on the urgency surrounding the initial conditions creating refugee status, but becomes noticeably more deferential if the criminal justice system is invoked.

We have, then, a proliferation of "self-contained"123 treaty regimes addressing one or more facets of migrant workers' experiences. In some cases, treaties appear to be converging on the legal norms applicable to migrant labor. In others, divergence is clearly visible. In still others, there is at least potential ambiguity created by silence, as when general human rights norms are not mentioned in other more specialized treaties.

These convergences and divergences can yield concrete problems of legal interpretation. Consider the following hypothetical instances of intertreaty conflict on migrant workers' rights (assuming all states involved are party to all the mentioned treaties):

1. Country $X$ regularly arrests, detains, and deports undocumented migrant workers without a public hearing, in conjunction with the criminalization of the acts of procuring and possessing fraudulent identity documents required by the Crime Convention Protocol on Migrant-Smuggling. ${ }^{124}$ Human rights groups protest that such actions violate the workers' rights to criminal due process, but Country $\mathrm{X}$ responds that neither the Migrant-Smuggling Protocol nor the accompanying

123. INT'L LAW COMM'N, supra note 6.

124. The Migrant-Smuggling Protocol specifies that "Migrants shall not become liable to criminal prosecution under this Protocol for the fact of having been the object of conduct" criminalized by the Protocol such as the production of fraudulent identity documents. The phrasing of this exemption suggests, however, that active participation by migrants in their own smuggling would indeed properly render them subject to criminal prosecution under the Protocol. 
Crime Convention establishes any minimum standards in this respect.

2. Country $Y$ does not permit asylum seekers to work, leading refugee lawyers to argue that the 1951 Refugee Convention has been violated. Country $\mathrm{Y}$ responds that the Refugee Convention applies only to recognized refugees, leaving asylum seekers with the lesser protections of the Migrant Workers' Convention and the ILO Conventions, which leave to Country $\mathrm{Y}$ the prerogative to grant work authorization.

3. Country $X$ establishes a visa system that provides workers from Country $Y$ with more favorable rules than those from Country $Z$. Country $Z$ protests that such distinctions violate the human rights of $Z$ citizens to nondiscrimination under the Civil and Political Covenant as interpreted by the Human Rights Committee. Country X responds that the WTO General Agreement on Trade in Services permits distinctions among nationals in visa systems and provides that such distinctions are not violations of the Most-Favored Nation Treatment principle according to the GATS Annex on the Movement of Natural Persons.

4. Country $Z$ prohibits undocumented migrant workers from participating in trade unions. Country $Z$ states that the ILO Conventions applicable to migrant workers specify organizing rights for lawful workers only. Trade union lawyers argue that these workers are entitled to participate in trade unions under both the Civil and the Political Covenant and the Migrant Workers' Convention, as well as under the ILO conventions on freedom of association and collective bargaining.

In each of the above problems, which side would prevail?

The apparent existence of gaps, conflicts, and ambiguities in the articulation of diverging legal rules from different regimes need not compel the conclusion that the legal relationship among these regimes cannot be resolved or that a single applicable legal rule cannot be identified. In other words, the divergences that result from plural legalities need not lead to a conclusion of international legal fragmentation. Indeed, to a remarkable extent, international lawyers can resolve apparent divergences in favor of the interpretive construction of a consistent, rather than conflicted, legal order. 
First, in some cases the texts of treaties themselves seek harmonization, incorporating other treaty systems by reference, or limiting their applicability in order to preserve a clear order among otherwise potentially competing rules. For example, the Migrant Workers' Convention explicitly excludes refugees and stateless persons. ${ }^{125}$ The Convention also explicitly places itself below any other more favorable treatment available from other applicable treaties. ${ }^{126}$ The Crime Convention Protocols on Trafficking in Persons and Migrant-Smuggling also contain "saving" clauses that clearly preserve the applicability of rules from elsewhere in international law, including international human rights law. ${ }^{127}$

In other cases, the treaties do not incorporate other rules authoritatively, but nevertheless endorse a posture of harmonization and compatibility. Thus, for example, the ILO Migration for Employment Convention provides that states parties "undertake[] to respect the basic human rights of all migrant workers," 128 thus encouraging the view that it should be read as complementary to, rather than conflicting with, human rights treaties that might offer more favorable treatment.

Even where there is no basis in the text or supporting documents, such as travaux preparatoires or treaty body interpretations for construing a relationship between treaties, international law does provide a series of tools for addressing potential conflicts. The Vienna Convention establishes broad principles of interpretation that encourage any given treaty provision to be read in conjunction with all other "relevant rules of international law." 129 More specifically, the Vienna Convention on the Law of Treaties establishes two somewhat mechanical techniques for resolving conflict: first, where there is a dispute in which the states are subject to differing treaties, the treaty to which all states are parties applies, ${ }^{130}$ and, second, that where earlier and later treaties conflict, the earlier treaty applies only to the extent that it is not incompatible with the later treaty. ${ }^{131}$

The Vienna Convention's somewhat mechanical approach, however, has proven less useful with the rise of self-contained and specialized regimes in which chronology may not reliably indicate the states' intent

125. Migrant Workers ' Convention, supra note 30, at Art. 3.

126. Id. at art. 81 ("Nothing in the present Convention shall affect more favourable rights or freedoms granted to migrant workers and members of their families by virtue of: (a) The law or practice of a State Party; or (b) Any bilateral or multilateral treaty in force for the State Party concerned.")

127. See Migrant Workers' Convention, supra note 30.

128. ILO Supplementary Provisions Convention, supra note 36, at art. 1.

129. Vienna Convention on the Law of Treaties, 1155 U.N.T.S. 331, art. 31 (May 23, 1969) [hereinafter Vienna Convention].

130. Id. at art 30(4).

131. Id. at art 30(2). 
with respect to earlier, potentially applicable treaties. Here, too, international law seeks to resist an outcome of outright conflict, establishing principles for order among regimes that cannot be simply differentiated on the basis of chronology or membership. The International Law Commission's important report on fragmentation highlighted two of these tools. First, the principle of harmonization holds that, where possible, rules of international law should be read "to give rise to a single set of compatible obligations." 132 Second, the maxim lex specialis derogat legi generali would allow the more specifically tailored rule to apply to govern in the case of a potential conflict. ${ }^{133}$ With these principles, international law aspires to become a single, internally consistent set of rules notwithstanding the emergence of specialized regimes. ${ }^{134}$

Applying these textual and doctrinal tools of interpretation to the above hypothetical problems, they appear resolvable in ascending levels of difficulty. Problem \#1 is simply a matter of textual application: human rights groups can reference the "saving" clause in the Migrant Smuggling Protocol. As for Problem \#2, the argument can be made that the ILO conventions are intended to preserve intact the rights of refugees, given the ILO Supplementary Provisions Convention's reference to the "human rights of all migrant workers." Similarly, the Migrant Workers' Convention excludes refugees and explicitly defers to more favorable treatment found in the Refugee Convention or elsewhere. The Refugee Convention does not clearly distinguish between recognized refugees and asylum seekers. This textual silence, however, is resolved through reference to both state practice and UN treaty bodies, each of which has established the distinction between asylum seekers and recognized refugees. Thus, in Problem \#2 a hierarchy of norms is clearly demarcated, leaving asylum seekers with the protection available from human rights generally but without the rights specifically granted to refugees under the Refugee Convention. ${ }^{135}$

Problem \#3 reformulates one of the most challenging areas of potential treaty regime conflict, between trade and human rights. Where trade rules are silent as to human rights, should this be taken as incorporation by reference so that the rules should be read complementarily, or, on the other (2006).

132. INT'L LAW COMM'N, UNITED NATIONS REPORT OF THE 58TH SESS. 428 (UN Doc. A/61/10)

133. Id. at 428 .

134. Id. at 427 ("International law is a legal system. Its rules and principles (i.e. its norms) act in relation to and should be interpreted against the background of other rules and principles. As a legal system, international law is not a random collection of such norms. There are meaningful relationships between them. Norms may thus exist at higher and lower hierarchical levels, their formulation may involve greater or lesser generality and specificity and their validity may date back to earlier or later moments in time").

135. See WEISSBRODT, supra note 3 , at 110-33. 
hand, does a trade rule "preempt" (even if it chronologically postdates) any other potentially applicable rule? Much has been made of this "linkage" question, though to date few have perceived the potential extension of this question to the issue of the treatment of migrant workers. In trade scholarship, however, a viewpoint appears to be emerging in line with the position of the International Law Commission discussed above, that sees both trade and human rights rules as part of a larger system of international law, with particular provisions from particular regimes to be read as part of a single legal system. ${ }^{136}$ On this view, certain prohibitions against visabased discrimination that arise from human rights law, for example visa systems that can be proven discriminatory on racial grounds, ${ }^{137}$ should be read as qualifications to the WTO's permission of nationality-based visa systems.

Problem \#4 also cannot be solved on the face of the treaty texts themselves, which do not specify their doctrinal relationships to each other. Turning to surrounding interpretation, the ILO freedom of association and collective bargaining conventions are, as a general matter, held to apply to all ILO members regardless of whether they have formally been ratified. ${ }^{138}$ However, should these conventions prevail over the narrower protections of the specialized ILO Migration for Employment Convention when it has also been ratified?

In this case, the maxim of lex specialis might allow the narrower rule to prevail. On the other hand, the importance of freedom of association as a "core" ILO labor standard might qualify it as a "non-derogable" or jus cogens norm in the labor law context, allowing an override of the lex specialis maxim. Only a very small number of human rights norms, such as prohibition of slavery and forced labor, however, have been universally

136. Robert Howse \& Ruti G. Teitel, Beyond the Divide: THE COVEnANT ON ECONOMIC, SOCIAL AND CULTURAL RIGHTS AND THE WORLD TRADE ORGANIZATION (2007); JOOST PAUWELYN, CONFLICT OF NORMS IN PUBLIC INTERNATIONAL LAW: HOW WTO LAW RELATES TO OTHER RULES OF INTERNATIONAL LAW (2003).

137. See id.

138. See ILO Declaration on Fundamental Principles and Rights at Work, supra note 34, 12 . This interpretation has been affirmed in numerous concrete instances. For example, the ILO Committee on the Freedom of Association found wanting the U.S. Supreme Court decision in Hoffman Plastic Compounds, Inc. v. National Labor Relations Board, 535 U.S. 137 (2002) in which labor law remedies were denied to undocumented workers. The Committee observed that "the impact of Hoffman ... includes undocumented workers hired by employers in full knowledge of their status and who may subsequently be dismissed for exercising their fundamental right to organize in an effort to ensure respect for basic worker's rights." INT'L LAB. ORG. COMM. ON THE FREEDOM OF ASSOCIATION, COMPLAINT AGAINST THE UNITED STATES (2003). The Committee concluded that "the remedial measures left [under U.S. labor law] in cases of illegal dismissals of undocumented workers are inadequate to ensure effective protection against acts of anti-union discrimination." Id. If 610 . (emphasis added). 
recognized as jus cogens, so the analysis of non-derogability would require consideration of multiple contextual factors. ${ }^{139}$

Reference to some ILO jurisprudence and supporting work by eminent labor law jurists ${ }^{140}$ points in favor of upholding the broader over the narrower standard. First, the ILO Constitution provides that "in no case shall the adoption of any Convention or Recommendation by the conference, or the ratification of any Convention by any Member, be deemed to affect any law ... which ensures more favourable conditions to the workers concerned." 141 This provision was intended to refer only to the relationship between national and international labor standards, rather than to a conflict between international labor standards. ${ }^{142}$ However, some international labor law specialists have argued that extension of this logic to conflicts between international instruments is supported by the "'progressive' nature of labor law" and its normative commitment to social progress, suggesting that "in the event of conflict, preference must be given in principle to the standard which is the most favourable to workers."143 Moreover, the ILO's compliance monitoring practices reflect the "principle of the independent character of concurrent treaties" in which a state bound by different standards remains bound to each. ${ }^{144}$

On the other hand, other supporting material from the ILO suggests that states should be able to establish differential labor standards for migrant workers in general and undocumented migrant workers in particular. The ILO's 2006 non-binding guidelines on labor migration exemplify this more cautious posture. ${ }^{145}$ The guidelines do state a commitment to a "rights-based approach"146 and further state a preference for the extension of all international labor standards to migrant workers. ${ }^{147}$ However, they are careful to preserve sovereign discretion in this regard by providing that "international labour standards apply to migrant workers, unless otherwise stated." 148 Moreover, the guidelines reaffirm the limited

139. The International Law Commission specifies several factors to be weighed in a balancing-type analysis: Whether such prevalence may be inferred from the form or the nature of the general law or intent of the parties, wherever applicable; whether the application of the special law might frustrate the purpose of the general law; whether third party beneficiaries may be negatively affected by the special law; and whether the balance of rights and obligations, established in the general law would be negatively affected by the special law. FRAGMENTATION OF INTERNATIONAL LAW, supra note 6, at 410 .

140. Cf. Statute of the International Court of Justice, art. 38(1)(d).

141. ILO Constitution, art. 19(8).

142. VALTICOS, supra note 55 , at 73.

143. $I d$.

144. Id.

145. ILO, MUltilateral Framework on Labour Migration: NON-BINDING PRINCIPLES AND GUIDELINES FOR A RIGHTS-BASED APPROACH TO LABOUR MIGRATION (2006).

146. Id. at 2 .

147. Id. at 16 .

148. Id. (emphasis added). 
position of the ILO Migration for Employment Convention that guarantees equality only between nationals and regular migrant workers. ${ }^{149}$ These guidelines make no mention of the "progressive" interpretive lens advocated by some jurists. Rather, they reaffirm a pragmatism that ultimately defers to sovereign territorial control and refrains from casting even core ILO labor standards in contravention of that deference insofar as migration is concerned. The guidelines therefore suggest that the narrower ILO Migration for Employment should prevail over the broader scope of the ILO conventions on freedom of association and collective bargaining.

Coming back to Problem \#4, the doctrinal murkiness created by divergences in the ILO's interpretive approaches may nevertheless be dispelled through deployment of the more mechanistic chronological rule set out by the Vienna Convention on the Law of Treaties. ${ }^{150}$ The chronological test would ultimately uphold the broader UN Migrant Workers' Convention rule, which allows trade union participation to undocumented migrant workers, to prevail, assuming that the state ratified the 1990 UN Convention at a date later than the 1949 Migration for Employment Convention. Thus, looking to treaty body interpretations and applying general rules of construction would probably resolve Problem \#4 by recognizing an expansive interpretation of the right to organize in the UN Migrant Workers' Convention and broader ILO jurisprudence emerging over the narrower ILO Migration for Employment Convention position.

The above section demonstrates that international lawyers possess tools of interpretation that can respond in many cases to the appearance of incoherent or conflicting rules. Those tools, however, retain the characteristics of legal analysis in any context: though some answers can be neatly solved on the basis of established "bright-line" rules, otherssuch as the latter two problems hypothesized above-necessitate an active engagement with underlying normative commitments as well as a metalevel commitment to coherence in the international order. In other words, doctrinal divergences ultimately do expose the politics of plural legalities, even if those divergences can be knit back together through mechanisms of legal interpretation.

149. Id. ("In formulating national law and policies concerning the protection of migrant workers, governments should be guided by the underlying principles of the Migration for Employment Convention ... particularly those concerning equality of treatment between nationals and migrant workers in a regular situation. ...") (emphasis added).

150. The Vienna Convention on the Law of Treaties is pertinent to the resolution of apparent conflicts in international labour obligations. See VALTICOS, supra note 55, at 74 . However, according to international labor law experts, the Vienna Convention should be applied only where principles are not available from within the specialized jurisprudence of labor law. See id. at 73-74. This hierarchy of interpretive practices of course itself reflects the Vienna Convention's maxim of lex specialis. 


\section{NORMATIVE CONVERGENCES AND DIVERGENCES}

The international lawyer's concern in the face of fragmentation is not only doctrinal incoherence, but a dissolution of the overall aspiration toward a harmonious international order. The concern is that:

specialized law-making and institution-building tends to take place with relative ignorance of legislative and institutional activities in the adjoining fields and of the general principles and practices of international law. The result is conflicts between rules or rule-systems, deviating institutional practices and, possibly, loss of an overall perspective on the law. ${ }^{151}$

Underneath the doctrinal question lies the specter of conflicting politics that give rise to normative fragmentation: "normative orders that are fundamentally different in their underlying conceptual structure." 152 As the International Law Commission's Report on Fragmentation remarked:

'Trade law' develops as an instrument to regulate international economic relations. 'Human rights law' aims to protect the interests of individuals and 'international criminal law' gives legal expression to the 'fight against impunity.' Each rule-complex or 'regime' comes with its own principles, its own form of expertise and its own 'ethos,' not necessarily identical to the ethos of neighboring specialization. ${ }^{153}$

Legal regimes can collide with each other not only in their specific rules, but also in their larger goals. Thus, if as the report suggests, the general thrust of trade law is to liberalize markets, ${ }^{154}$ and the general thrust of human rights law is to protect individuals, ${ }^{155}$ and the general thrust of labor law is to support workers, ${ }^{156}$ these regimes tend not to reach, formally or informally, the issues posed by illegal migration. At the same time, the general effect of criminalization, promoted both internationally and nationally, may be viewed as hostile not only to the liberalization of markets for migrant labor, but possibly also to the protection of individual migrant workers.

"Global legal pluralism ... is not simply a result of political pluralism, but is instead the expression of deep contradictions between colliding

151. INT'L LAW COMM'N, supra note 9, at 11.

152. Merry, supra note 1 , at 873.

153. INT'L LAW COMM'N, supra note 9, at 14.

154. The normative focus of international trade law on liberalization has been contested those who would emphasize the trade regime's origination in a Fordist "embedded liberalism" that viewed deregulation of trade as only one of a variety of governmental tools aimed at achieving full employment and social welfare. See, e.g., Robert Howse, From Politics to Technocracy and Back Again: The Fate of the Multilateral Trading System, 96 AM. J. INT'L L. 94 (2002).

155. For a discussion of some of the internal complexities and external compromises of human rights law, see DAVID KENNEDY, THE DARK SIDES OF VIRTUE (2004).

156. For a brief discussion of internal normative rifts between "economic and social" aspects of the ILO, see supra notes 17-19 and accompanying text. 
sectors of a global society."157 Aleinikoff has conceptualized international law on migration, similarly, as dividing into three general categories: those treaties that see migration in terms of labor flows, those that see it as a question of human rights, and those that emphasize state control and security. ${ }^{158}$

Among these three, the realm that most challenges "traditional notions of state sovereignty," 159 is that of human rights. International human rights law formally extends liberal egalitarianism farther than international trade or labor law, although how far depends on interpretive questions that have yet to be resolved. At the same time, multilateral human rights enforcement is ineffective in terms of the provision of recourse for individual claimants. ${ }^{160}$ The Migrant Workers Convention is hampered by a lack of signatories. The Criminal and Political Covenant, although it has more signatories and so could presumably be used to reinforce the principle of protecting the human rights of undocumented migrant workers, is limited in its ability to offer any recourse to right-holders. In addition, signatories like the United States would argue, albeit not without controversy, that their reservations to the treaty restrict potential right-holders to that recourse offered under domestic constitutional law. ${ }^{161}$

The relative ineffectiveness of human rights regimes has led some commentators to call for a more trade-centered approach to migration. ${ }^{162}$ Such an approach falters on the belief, central to many in international labor law, that "labor is not a commodity."163 Nevertheless, some scholars have argued that an economic approach may in fact yield the greatest welfare for

157. Andreas Fischer-Lescano \& Gunther Teubner, Regime-Collisions: The Vain Search for Legal Unity in the Fragmentation of Global Law, 25 MICH. J. INT'L L. 999, 1004 (2004).

158. T. Alexander Aleinikoff, International Legal Norms on Migration: Substance without Architecture, in INTERNATIONAL MIGRATION LAW: DEVELOPING PARADIGMS AND ChALlENGES 467 (Ryszard Cholewinski, Richard Perruchoud \& Euan MacDonald eds., 2007).

159. Id. at 469 ("human rights discourse counterbalances traditional notions of state sovereignty, which view states as possessing unbridled authority to regulate immigration").

160. Regional human rights systems may harbor more potential. See Connie de la Vega and Conchita Lozano-Batista, Advocates Should Use Applicable International Standards to Address Violations of Undocumented Migrant Workers' Rights in the United States, 3 HASTINGS RACE \& POVERTY L.J. 35 (2005) (describing the Inter-American human rights system).

161. See 138 Cong. Rec. S4, 781-01 (Apr. 2, 1992) (setting forth Senate reservations to the Civil and Political Covenant). For challenges to the validity of reservations, see Lori F. Damrosch, The Role of the United States Senate Concerning "Self-Executing" and "Non-Self-Executing" Treaties, 67 CHI.KENT L. REV. 515 (1991); David Weissbrodt, The United States Ratification of Human Rights Covenants, 63 MINN. L. REV. 35 (1978).

162. See, e.g., Howard F. Chang, Liberalized Immigration as Free Trade: Economic Welfare and the Optimal Immigration Policy, 145 U. PA. L. REV. 1147 (1997).

163. INT'L LAB. ORG., supra note 18. For a discussion of the conceptual and legal challenges to viewing migrant labor as trade, see Jennifer Gordon, Explaining Immigration Unilateralism, 104 NW. U. L. REV. 3 (2010). 
the world's workers, making the case for the liberalization of migrants' rights in the economist's language of gains from trade. ${ }^{164}$

The trade regime also would appear to hold the attraction of greater institutional effectiveness than the human rights regime. As the discussion above has suggested, however, the WTO has proven extremely pragmatic in its extension of institutional authority to the question of migration and labor regulation. Despite the relative strength of the World Trade Organization generally, the existing subdivision governing trade in services is much less effectual. This is because, as indicated above, in services the basic WTO disciplines of nondiscrimination and national treatment apply only to those sectors that are voluntarily made subject to them-in contrast to the rules governing trade in goods or intellectual property, where these principles automatically apply. ${ }^{165}$ And within the relatively weak division of trade in services, those provisions governing migrant (temporary) labor are the weakest and most qualified. The practical effect of the trade regime is to confer the privileges of liberalization only to high-skilled workers. The GATS by itself establishes almost no baseline, leaving the issue almost entirely to the political will of states.

Within this arena of interstate relations and politics, the WTO has managed to attract some attention to the issue of migrant labor. For the first time ever, the WTO is fielding serious proposals by member states to include negotiations on low-skilled labor migration. WTO members are currently engaged in the "Doha" Round of Negotiations, launched by the 2001 WTO Ministerial Conference and accompanying Ministerial Declaration (the "Doha Declaration") setting forth goals for negotiations. The Doha Declaration states that "negotiations on trade in services shall be conducted with a view to promoting the economic growth of all trading partners and the development of developing and least-developed countries."166 The negotiations on trade in services are expected to form an important part of the results for the Doha round. The Declaration calls for a focus on rules governing movement of natural persons and the effect of those rules on prospects for development.

Developing-country members of the WTO are increasingly concerned with addressing low-skilled labor migration head on, particularly since many are significant exporters of such labor. Several countries have offered proposals that would elaborate rules on the movement of natural persons, and some of these proposals directly link movement of natural persons with

164. See, e.g., Jagdish Bhagwati, In Defense of Globalization (2004); Trachtman, supra note 10 .

165. The Doha round includes an effort to expand the commitments under trade in services; since it is subject to controversy, it is uncertain how this will turn out.

166. Ministerial Declaration, WT/MIN(01)/DEC/1 (Nov. 14, 2001). 
development. ${ }^{167}$ Perhaps the boldest call, however, has come from the United Nations Development Programme, which has urged the negotiation of WTO rules liberalizing constraints on low-skilled labor migration. ${ }^{168}$ There have also been some negotiations regarding creating a basis for easier authorization of workers who fall into the GATS categories. The so-called GATS visa has been promoted by the Indian government, and also by U.S. and European businesses. ${ }^{169}$ This would effectively amend the GATS Annex on the Movement of Natural Persons. However, with the Doha negotiations in serious trouble for a host of reasons, the likelihood that WTO Members will martial the political will necessary to extend significantly GATS coverage is limited.

As suggested at the beginning of this section, state control and security represent an important part of the normative spectrum in international law affecting migrant labor. Whereas both human rights law and trade law can be viewed as normatively driven by liberal individualism, each in different ways recognizes the counterbalancing effect of the state, either explicitly, or implicitly in institutional effect. Nevertheless, it might be argued that in these areas of international law, at least conceptual primacy lies explicitly with liberalism, and posits the state as a limiting factor. By contrast, the set of treaties coordinating states' treatment of transnational crime-the Crime Convention and the accompanying protocols on trafficking in persons and migrant-smuggling - shift normative emphasis to state security. In these instruments, state control and security are paramount, with individual rights operating as the limiting factor.

There is no necessary doctrinal conflict between the "crime" treaties and their counterparts in human rights, labor, and trade law insofar as migrant workers are concerned, as Section II.F. above demonstrates. Even where no doctrinal divergence exists, however, the crime treaties potentially represent a normative divergence. As a normative matter, the crime treaties may reinforce an association of migration with dangerous and threatening criminal activity. The treaties establish bases for coordinating

167. See Communication from India, Proposed Liberalization of Movement of Professionals, S/CSS/W/12 (Nov. 24, 2000); Communication from United States, Movement of Natural Persons, S/CSS/W/29 (Dec. 18, 2000); Communication from Japan, Negotiating Proposal on Temporary Movement of Natural Persons, S/CSS/W/4/S.2 (July 1, 2001); Communication from EC, Negotiating Proposal on Temporary Movement of Service Suppliers, S/CSS/W/45; Communication from Canada, Negotiating Proposal on Temporary Movement of Natural Persons Under GATS (Mode 4), S/CSS/W/48 (Mar. 14, 2001); Communication from Colombia, Negotiating Proposal on Temporary Movement of Natural Persons, S/CSS/W/97 (July 9, 2001).

168. United Nations Development Programme: Making Global Trade Work for People (2003).

169. Richard Self \& B.K. Zutshi, WTO-World Bank Symposium on Movement of Natural Persons (Mode 4) Under the GATS: Temporary Entry of Natural Persons as Service Providers: Issues and Challenges in Further Liberalization under the Current GATS Negotiations (Apr. 11, 2002). 
the policing of borders against illegal migrants, ${ }^{170}$ by allowing states to extend immigration-related investigations extraterritorially into commercial carriers under the control or auspices of other states parties, ${ }^{171}$ and by consolidating repatriation practices for both "smuggled migrants" and "trafficked persons." 172

The crime treaties are much more explicit and detailed in their treatment of border control, of course, than the counterpart treaties in trade, labor, or human rights. They give fairly detailed guidelines ${ }^{173}$ for the coordination of law enforcement among member states in combating these criminal offenses. ${ }^{174}$ If a state party refuses the request of another state party to extradite an individual, it becomes subject to an obligation to prosecute that individual internally. ${ }^{175}$ There are also extensive provisions regarding "mutual legal assistance" during the stages of criminal investigation that antecede formal indictment and extradition. ${ }^{176}$ The Trafficking Protocol, of course, has at its center the goal of reducing the suffering of victims of "modern-day slavery." To that end, the Protocol

170. See Migrant Smuggling Protocol, supra note 40, at art. 11(1) ("Without prejudice to international commitments in relation to the free movement of people, States Parties shall strengthen, to the extent possible, such border controls as may be necessary to prevent and detect the smuggling of migrants.").

171. See id; Trafficking Protocol, supra note 41, at art. 11.

172. See, e.g., Migrant Smuggling Protocol, supra note 40, at art. 18(1) ("Each State Party agrees to facilitate and accept, without undue or unreasonable delay, the return of a person who has been the object of conduct set forth in article 6 of this Protocol and who is its national or who has the right of permanent residence in its territory at the time of return."); Trafficking Protocol, supra note 41, at art. 8 (1) ("The State Party of which a victim of trafficking in persons is a national or in which the person had the right of permanent residence at the time of entry into the territory of the receiving State Party shall facilitate and accept, with due regard for the safety of that person, the return of that person without undue or unreasonable delay.").

173. There is also a more general obligation to cooperate. See Crime Convention, supra note 39 , at art. 27 ("States Parties shall cooperate closely with one another, consistent with their respective domestic legal and administrative systems," especially in aid of conducting inquiries regarding identity of persons or property related to crimes; and general exchange of information). The Crime Conventions has established progressively more extensive obligations relating to extradition. For an account of this progression toward "thick" institutional obligations, see Chantal Thomas, Disciplining Globalization, 24 MiCH. J. INT"L L. 549 (2004) ("The 2000 Convention . . . developed additional mechanisms to increase efficacy in criminal enforcement . . . expanded subject matter jurisdiction . . . encourages the use of "special investigative techniques, such as electronic or other forms of surveillance and undercover operations" to aid enforcement ... . and requires members to "institute a comprehensive domestic regulatory and supervisory regime for banks and non-bank financial institutions . . . in order to deter and detect all forms of money laundering.").

174. A state party to the Crime Convention must ensure a minimum domestic criminal law environment by establishing formal sanctions for the Convention's defined criminal offenses. See Crime Convention, supra note 39, at art. 11. States Parties must make criminal such offenses not only when they involve a transnational component, but also even if they are wholly domestic. Id. at art. 34 .

175. See Crime Convention, supra note 39, at art. 16(10) ("A State Party in whose territory an alleged offender is found, if it does not extradite such person in respect of an offence to which this article applies solely on the ground that he or she is one of its nationals, shall, at the request of the State Party seeking extradition, be obliged to submit the case without undue delay to its competent authorities for the purpose of prosecution.").

176. See Crime Convention, supra note 39, at art. 18 . 
does contain language promoting the protection of human rights of trafficking victims. However, whereas the Protocol's language relating to criminalization and repatriation establishes mandatory obligations, the provisions relating to assistance of victims and human rights protection are aspirational. ${ }^{177}$

The crime treaties also appear quite robust institutionally when compared with their counterparts in trade and human rights. They have many more participating members than the UN Migrant Workers Convention, the ILO migrant labor conventions, or the General Agreement on Trade in Services. ${ }^{178}$ Moreover, unlike the former, the international criminal law treaties contain a great deal of administrative obligationsspecifications as to how states parties should go about implementing the treaty's provisions. The apparatus established by these conventions is thus much broader in its purview and its authority.

Both because of their explicit normative emphasis on security, and because of their institutional authoritativeness, the crime treaties may create an effect of throwing a shadow of suspicion over entire regions of the world that are viewed thereafter as suppliers of criminality. Certainly, in a post9/11 world in which major political powers have declared an ongoing state of heightened alert, the social atmosphere may be one in which popular concerns in developed countries around increased economic instability in the globalization era very easily dovetails with increases in perceived criminal dangers beyond borders.

The normative ordering described above could, by some, be perceived as a legitimate, if controversial, corollary of the sociolegal facts of national identity, territorial sovereignty, and citizenship. However, the social benefits of policing identity must be considered in light of the probable social costs, which include the ironic, or tragic, likelihood that criminalizing

177. Compare Trafficking Protocol, supra note 41, at art. 5 on criminalization (states "shall ... establish as criminal offenses") and art. 8 on repatriation (states "shall facilitate and accept ... the return of [a "victim of trafficking"]") with id. at art. 6 on the establishment of social services programs (states "shall consider implementing measures to provide for the physical, psychological and social recovery of victims") and art. 7 on the status of victims (states "shall consider adopting . . . measures that permit victims of trafficking ... to remain in ... territory").

178. Although all WTO members are formally signatories to the GATS, the fact that GATS principles apply only to those sectors for which Members have actively made concessions, and the fact that only a minority of Members have made such concessions, effectively means the level of participation is low. See Sungjoon Cho, Development by Moving People: Unearthing the Development Potential of a GATS Visa, in DEVELOPING COUNTRIES IN THE WTO LEgAL SYSTEM 457 (Joel P. Trachtman \& Chantal Thomas eds., 2009) (stating that the "the ratio of full liberalization in Mode 4 market access ranges from 0 to $4 \%$, compared with $18-59 \%$ in Mode 1 (cross-border, such as ecommerce), $24-69 \%$ in Mode 2 (consumption abroad, such as foreign outpatients), and $0-31 \%$ in Mode 3 (commercial presence, such as foreign subsidiaries."). 
markets in many cases probably does not decrease them, but only renders them more violent. ${ }^{179}$

\section{CONCLUSION: POLITICS AND PluRAL LEGALITIES}

The above sections have examined international legal regimes potentially governing migrant labor. The foregoing has argued that disparate treaties may converge or diverge both doctrinally and normatively. On the one hand, the principle of nondiscrimination can challenge sovereignty, reflecting the logical extension of a liberal legal internationalism that paradoxically consumes its own original subjects, the states that established it. In this progressionist narrative, aspects of the legal identity of states, including the right to police borders, become increasingly challenged. On the other hand, against this dynamic of liberalism, an antagonistic or mediating principle of the necessity for policing and border control can be seen in all the treaties analyzed above, but most clearly in the regime of criminalization. In this view, it is precisely the larger liberalization of orders that justifies and requires states to intervene to prevent illegality and to preserve the underlying construct of the original order.

In the former view, migrant workers register primarily as human beings. Their legal subjectivity becomes relevant under a conceptual and doctrinal paradigm that identifies individuals as the ultimate and sacrosanct constituents of law. The latter view adopts a lens of sovereignty that continues to see states as the primary occupants of the legal terrain, with both rights and responsibilities relating to territoriality. Here, migrant workers register primarily as objects of governance in a paradigm that privileges border control as a prerogative of states.

For a topic as politically fraught as immigration, and particularly immigrants who are active participants in domestic job markets, this normative tension becomes even more important. From a migrant worker advocate's perspective, where there is divergence, there is the danger that the divergence will be exploited by those hostile to non-citizens as a group; that is, that more antagonistic norms toward migrant workers will prevail. ${ }^{180}$

Indeed, the emergence of different rule systems within human rights, labor, trade, and crime regimes in international law appears to embody not

179. Chantal Thomas, Undocumented Migrant Workers in a Fragmented International Order, 25 MD. J. INT'L L. 187 (2010).

180. Cf. WEISSBRODT, supra note 3, at 37 (identifying the general problem that "treaties function as creating common moral standards" but gaps can allow countries to justify "noncompliance" and in particular the problem that "international law and thematic mechanisms relating to non-citizens have [traditionally] focused on non-citizen sub-groups while neglecting broader protections for non-citizens as a whole" and calling for "clear, comprehensive standards governing the rights of non-citizens"). 
just legal pluralism, but also legal fragmentation: "the emergence of specialized and (relatively) autonomous rules or rule-complexes, legal institutions, and spheres of practice."181 These self-contained systems may diverge at the level of the overarching set of principles or the "ethos"182 of a system of laws. Some commentators have responded to the plural legalities of international migration by calling for consolidation: an international "Bill of Rights" for migrant workers, ${ }^{183}$ for example, or more ambitiously, an institution such as a "World Migration Organization." 184 Others assert that normative convergence is already building not only in the academy but also in practice and in policy, ${ }^{185}$ through various "modes of norm production, regime creation and management" that include international conventions, regional norms, customary international law, national implementation processes, and state cooperation. ${ }^{186}$

For these jurisprudential discourses, important questions are posed by convergence and divergence in the way treaties address migrant workers in terms of both specific doctrinal questions and underlying norms and principles.

If for jurists, this untidiness is disconcerting, for those with even higher stakes it is more so. For advocates of migrant worker rights, the fractured quality of laws on migrant labor may illuminate the depth of the gap between treaties as "standards of global justice" and the reality that migrant workers may face.

181. INT'L LAW COMM'N, supra note 6, at 9.

182. INT'L LAW COMM'N, supra note 134, at 11.

183. Aleinikoff, supra note 4 , at 477.

184. See, e.g., Jagdish Bhagwati, The World Needs a New Body to Monitor Migration, FINANCIAL TIMES, Oct. 24, 2003, at 24; Bimal Ghosh, Towards a New International Regime for Orderly Movements of People, in MANAGING Migration: TIME FOR A NEW INTERNATIONAL REgIME? 6 (Bimal Ghosh ed., 2000).

185. See HOWSE \& TEITEL, supra note 140. A number of intergovernmental dialogues on migration, such as the UN High-Level Dialogue on International Migration and Development, September 14-15, 2006, and the Berne Initiative of the Swiss Federal Office for Refugees, and the Global Migration Group. Several intemational organizations maintain extensive ongoing policy divisions on intergovernmental coordination, such as the International Organization for Migration's Commission on Global Governance. For more information on such activities, see TRACHTMAN, supra note 10 , at $15-23$.

186. Aleinikoff, supra note 4 , at 471 . 
